\title{
The Shift Process in Transitivity System on Obama's and Trump's Inauguration Speech: A Translation Study
}

\author{
Taufik Nur Hidayat ${ }^{1 *}$; M.R.Nababan²; Djatmika² \\ ${ }^{1}$ Postgraduate Student in Linguistics and Translation, Sebelas Maret University, Indonesia \\ ${ }^{2}$ Faculty of Cultural Sciences, Sebelas Maret University, Indonesia \\ *Corresponding Author: taufiknurhidayat8888@gmail.com
}

\begin{abstract}
The purpose of this study is to describe the shift process which is caused by applying certain translation techniques. The techniques are modulation, transposition, implication, and reduction by Molina and Albir (2002). The research used descriptive qualitative-quantitative method by applying purposive sampling technique. The source of the data was the text of Obama's and Trump's inauguration speech and their respective translations. There were 152 data in each inauguration speech. The data were the clause which contains the process type which is realized in verbal group in English and its translation. Based on the total of research data, 10 data or $6.57 \%$ in Obama's inauguration speech and 7 data or $4.60 \%$ in Trump's inauguration speech was obtained. The obtained data was changing or shifting in process type from the original text into the target text (Indonesian). So, the result of the research supports the theory that modulation, implication, explication, and reduction can cause the shift, especially in verbal group.
\end{abstract}

Keywords: modulation; transposition; implication; reduction; shift of process types

\section{INTRODUCTION}

Equivalence is very important and it is decided by the competence or translator's ability in understanding source text and transferring it into target text. There are many experts of translation theory who state that the fundamental problem of translation is equivalence (Bielsa \& Bassnett, 2008; Catford, 1965; Nababan, 2012). The primary aim in translating is transferring the written information from source text into target text by considering the same equivalence effect (Newmark, 1988).

The argument above contradicts with Nida, E.A and Taber (1982) who said that translation consists in reproducing in the receptor language the natural equivalent of the source language message first in terms of meaning and secondly in terms of style. First, the meaning of equivalence in translation is more emphasized on the meaning of message or information which is within source language. Again, Catford (1965) stated that there are two kinds of equivalence. They are formal equivalence which is called category equivalence between source text translated in target text are the same. For example, translating the noun in the source text becomes the noun in target text. Second, textual equivalence which is linked with the content of the text includes the message or information, as well as the cohesion on the language shape within the text.

And then, according to Baker (2011), equivalence is the relationship between the source language and the target language. The notion of equivalence at different levels: at word level, equivalence above word level. These levels of equivalence are closely related to the translation process, including all different aspects of translation and hence putting together the linguistic and communicative approach.

It seems that all of them are almost the same, which is the concept of equivalence is meaning equivalence (text function) and form equivalence (grammatical structure). 
Furthermore, Tack (2000) in Santosa (2009) stated that translating the text is also considering the language metafunction. The difficulties in translating the meaning of textual function, ideational, and interpersonal will be found. Most of translation experts agree that the purpose of equivalence in translation is textual equivalence. In systemic functional linguistics point of view, equivalence involves all aspects in social semiotics such as sociocultural context, genre, and register.

The equivalence of genre includes the equivalence of genre types as well as its social function which is expected by original writer. For instance, the register equivalence includes a set of metafunction equivalence which is realized in text structure and its texture such as discourse semantic, lexicogrammar, phonology, and graphology.

A sentence consists of two levels; they are lexicogrammar and phonology (Halliday \& Matthiessen, 2014). In clause level, lexicogrammar will see the system or clause structure in realizing the ideational meaning, exactly experiential meaning. The grammar which realizes the clause structure and representing experiential ideational meaning is transitivity which is realized by verbal group (Halliday \& Matthiessen, 2014). Process is the core of phenomenon in an experience, either physical experience, mental, verbal, behavioral, relational, or existential. These kinds of process naturally decide the kinds of participants which are including the doer of process, verbiage, phenomenon, goal, or others. It depends on the kinds of process.

There are many scholars who discuss the transitivity system (Darani, 2014; De Dios, 2013; Idrus, Nor, \& Ismail, 2014; Isti 'anah \& Id, 2014; Matu, 2008) seen from ideational function, interpersonal, and textual. But all of them have not yet discussed the translation quality as a result of deciding the translation technique. There are many translation research studies by using SFL approach in current decade which emphasize on structure variation, for example nominal group research (Hidayah, 2013; Pramuditya, 2016; Purwaningsih, 2010). There are also many other translation research studies by using SFL such as discourse analysis, intralingua translation analysis, and theme shift (Hill-Madsen, 2014; Santosa, 2009; Sujono \& Wiratno, 2016). Their purpose is to analyze the shift kinds in translation and its structure. They have not yet discussed the translation technique and the effect on translation shift especially in transitivity.

Furthermore, there are some experts who study systemic functional linguistics as an approach which is reasonable to consider in analyzing the text (Santosa, 2009; Seo, 2013). Santosa (2009) discusses the equivalence in translation especially equivalence in text level such as text structure equivalence and texture equivalence. Seo (2013) discusses about the discourse and society by looking at the point of view in two different newspapers. The newspaper reports on the Libyan civil war tend to reflect the national interests of each country. The British Guardian newspaper tended to emphasize a Western prowar slant of humanitarian protection for Libya, whereas the Chinese People's Daily newspaper tended to focus on critical observer arguments about the process of the war.

Next, some previous studies related with transitivity analysis and verbal process conducted by some scholars (Ignatieva \& Rodríguez-Vergara, 2011; Isti'anah \& Id, 2014). The researches focused on the process type used in opinion and students' article to find out the genres of the text and find out the people's thought. However, those observed in the speech were still rarely found.

Speech can be used as measuring tools to know someone's ability to influence the audience by using the opinion and people's thought. Speech has a role to construct the influence. Speech is an interesting text to analyze by using SFL. If it is seen by its context, speech text has different language form. It depends on its speakers. In this translation study, the speech texts analyzed are Obama's and Trump's inauguration speech in White House, Washington DC, USA. As we all know, Obama was the first black president in the White House. He had a different background with Trump, the current president.

With regards to the above, equivalence is correspondence between source and target language; it must have certain strategy to obtain equivalence itself. This case is the way to translate the process which is realized in the verb as linguistic unit. The strategy is choosing the appropriate translation technique which is a tool for analyzing the translation. Of course, they have many categories to be analyzed such as text, context, and the process (Molina \& Hurtado Albir, 2002).

Modulation, transposition, implication, explication, and reduction are the most interesting techniques to study. This is because the translation using these techniques is usually changing or shifting, though in the grammatical level and not in meaning level. There are many research studies which stated that modulation and translation caused the shift (Hatim \& Munday, 2013; He \& Wen, 2015; Mardiana, 2014; Munday, 2009).

Finally, SFL is able to answer the need of language study as social semiotic. SFL is also able to be theoretical tools in linguistic studies either in macro or micro scope. Based on the review above, it gives big support in translation research which is combined with SFL as 
used approach. After this topic is studied, the research is expected to give the benefit and contribution in translating the process type. The translator should avoid certain techniques which can cause the shift structurally, although it cannot cause the meaning shift especially in translating process types which is realized by verbal group.

Based on the explanation above, the researcher is interested in studying the kinds of process shift caused by translation techniques. The research used the systemic functional framework theory by Halliday. It is known that the systemic functional theory is oriented towards language as a social process connected to a certain society and its culture which is realized by language metafunction. Systemic Functional Linguistics puts emphasis on the social function of language used, such as its use in a community in different social contexts.

\section{METHOD}

The research used descriptive quantitative-qualitative method with purposive sampling technique (Sutopo, 2006). The descriptive method draws the quantitative data obtained dealing with the subject or the phenomenon of the population as well as the researcher involved in the research. The qualitative data was obtained by analyzing the data to generalize into the phenomenon. So, the research can also be called embedded case study single case (Strauss, A., \& Corbin, 2003).

The data are the verbs which realized the process types and its translation. Qualitative data was obtained by content analysis, questionnaire, and in-depth interview in this case is focus on group discussion to classify the linguistic data (process type) and the translation data (translation technique and translation quality).

This study used Systemic Functional Linguistic Approach (Halliday \& Matthiessen, 2014). In the translation data, the research used the translation technique theory by Molina and Albir and in assessing the translation quality used in qualitative parameter by Nababan. The data source in the research is the document of speech text and its translation. Qualitative data validation used the source and method triangulation (Patton, 1980). In choosing the informants or validator, the research used the criterion-based selection sampling technique. Data analysis used domain analysis, taxonomy analysis, componential analysis, and culture theme analysis (Spradley, 1980).

\section{RESULTS AND DISCUSSION}

Based on the whole data research which is 152 data in
Obama's speech translation, it is obtained that 10 data $(0.65 \%)$ is changing from one process to another process in target text. It does not change the meaning significantly. Based on the result above, it can be concluded that there are 6 kinds of shift, namely: a) identifying relational process into attributive relational process is 2 data (1.32 $\%$ ); b) mental process into mental behavioral process is 2 data $(1.32 \%)$; c) material process into $\varnothing$ process is 2 data $(1.32 \%)$; d) attributive relational process into attribute conflated with process is 2 data (1.32\%); e) relational attributive into existential process is 1 datum $(0.66 \%)$; and $\mathrm{f})$ material process into attribute conflated with the process is 1 datum $(0.66 \%)$. While the shift of translation caused by 3 translation techniques. They are: a) 4 data (2.63\%) by implication; b) 4 data (2.63\%) by modulation; and c) 2 data (1.32\%) by using transposition.

While based on the whole data research which is 152 data in Trump's speech translation, it is obtained that 10 data $(0.65 \%)$ is changing from one process to another process in target text. It does not change the meaning significantly. Based on the result above, it can be concluded that there are 6 kinds of shift. They are: a) mental behavior process into attributive relational process is 1 datum $(0.65 \%)$; b) identifying relational process into attributive relational process is 1 datum $(0.65 \%)$; c) attributive relational process into attribute conflated with process is 1 datum $(0.65 \%)$; d) extra-causer process into attributive relational process into attribute conflated with process is 1 datum $(0.65 \%)$; e) material process into attributive relational process into attribute conflated with process is 1 datum $(0.65 \%)$; $\mathrm{f}$ ) mental behavioral process into attribute conflated with process is 1 datum $(0.65 \%)$; g) identifying relational process into existential process is 1 data $(0.65 \%)$. While the shift of translation caused by 4 translation techniques. They are: a) 4 data $(2.63 \%)$ by modulation; b) 1 data $(0.65 \%)$ by implication; c) 1 data $(0.65 \%)$ by using explication; and d) 1 data $(0.65$ $\%$ ) by reduction.

It can be concluded that the process shifts in two speeches above was caused by using modulation, implication, explication, and transposition technique. The process shifts here are the category of micro unit of the text which is relevant with the use of translation technique. Modulation is usually used by the translator to translate the text by changing the point of view either in form or its structure. Meanwhile, implication is the opposite form of explication. Explication expresses clearly and directly the meaning of the text. So, implication expresses the meaning implicitly or indirectly. The last technique is transposition. It is chosen because difference of language system. Transposition is used by changing the 
grammatical category from source text into target text. This is done because of the differences in linguistic rules between the two languages. This technique is similar to the modulation technique. The technique of transposition also has two properties: obligatory and optional. This technique can change the grammatical structure, so it can affect the shift of word class and the shift of both lexical and grammatical forms.

Finally, the findings of the research supported the translation technique theory that the translation technique roles in micro unit in the text. In addition, there are five characteristic of translation technique. The five characteristics of translation technique are: 1) affecting the result of the translation; 2) classified by comparison with the original; 3) affecting micro-units of text: 4) nature discursive and contextual; 5) functional (Molina \& Hurtado Albir, 2002)

Most experts in translation agree that one of the crucial problems in translation is equivalence (Baker, 2011; Catford, 1965; Newmark, 1988). Based on the research findings obtained, the effect of choosing the translation technique is shifting which is the translation will be changed either in structure or meaning. In this case, it is the changing in process type. Choosing the certain verbs will influence the process in the clause, including its participants. Process type is one of the elements of transitivity system which is realized in ideational meaning (Halliday \& Matthiessen, 2014). Ideational meaning is one of the metafunction or meaning in lexicogrammar stratum. According to Santosa (2009), the equivalence of lexicogrammar should involve the assessment of the three metafunction realized in the grammar. The unequivalence of the three meanings in ST and TT may result in the unequivalence of meaning in general or shift in language style.

Process shift which is found in this present research is in line with lexico-grammar equivalence concept which is introduced by Santosa (2009). In the research, theme-rhyme movement is one of the important things that should be obtained to develop the clause in lexico-grammar stratum. Between translation technique and lexicogrammar shift has close relationship. Process is one of the elements of transitivity system in a clause which realizes ideational meaning.

Transitivity analysis is important to observe how people symbolize the real world and social context. The findings of the research clearly support Halliday's theory that language was the mirror of their awareness by their reactions, cognitions, and perceptions, and also his linguistic acts of speaking and understanding (2014). People are excited to welcome the president's inauguration, especially in superpower country like the USA. Choosing SFL as an approach is very appropriate and suitable to answer the linguistics problem either in micro or macro level (Eggins, 2004; Halliday \& Matthiessen, 2014).

It seems that the research is supported by the SFL research done by Sujono \& Wiratno (2016) who studied about the shift types of theme. The conclusion indicated that the shift theme is caused by the difficulties to find out the theme structure in target language. Of course, the difficulties happen because of grammatical rule difference and difficulties in using the appropriate translation technique.

For evaluation of process shift and translation technique in the following result list was provided:

\section{Obama Speech Translation}

Table 1. Process Shift in Obama's Speech

\begin{tabular}{|c|l|l|c|c|}
\hline No & $\begin{array}{c}\text { Process in } \\
\text { ST }\end{array}$ & $\begin{array}{l}\text { Process in } \\
\text { TT }\end{array}$ & Freq. & Percentage \\
\hline 1. & IRP & ARP & 2 & 1.32 \\
\hline 2. & Mental & $\begin{array}{l}\text { Mental } \\
\text { behavior }\end{array}$ & 2 & 1.32 \\
\hline 3 & Material & $\emptyset$ process & 2 & 1.32 \\
\hline 4 & ARP & $\begin{array}{l}\text { Attribute / } \\
\text { process }\end{array}$ & 2 & 1.32 \\
\hline 5 & $\begin{array}{l}\text { Attribute/ } \\
\text { process }\end{array}$ & Existential & 1 & 0.65 \\
\hline 6 & Material & $\begin{array}{l}\text { Attributive/ } \\
\text { process }\end{array}$ & 1 & 0.65 \\
\hline \multicolumn{2}{|l|}{ Total Process Shift } & 10 & 6.55 \\
\hline
\end{tabular}

IRP: Identifying Relational Process; ARP: Attributive Relational Process

Based on the shift above, it is caused by three techniques applied by the translator. The techniques are drawn in a table as follows:

Table 2. Translation Techniques Caused the Process Shift

\begin{tabular}{|c|l|c|c|}
\hline No & $\begin{array}{c}\text { The technique } \\
\text { influence the shift }\end{array}$ & Frequency & Percentage \\
\hline 1 & Modulation & 4 & 2.63 \\
\hline 2 & Implication & 4 & 2.63 \\
\hline 3 & Transposition & 2 & 1.32 \\
\hline \multicolumn{2}{|l|}{ Total } & 10 & $6.57 \%$ \\
\hline
\end{tabular}


Based on the table above, it can be seen that the process shift between source text and target text caused by using modulation, implication, and transposition technique. Modulation is usually used by the translator to translate the text by changing the point of view either in form or its structure. Meanwhile, implication is the opposite form of explication. Explication expresses clearly and directly the meaning of the text while implication expresses the meaning implicitly or indirectly. It is caused by the difference of language system. The use of this technique makes the meaning easier to be understood in target text. The last technique which causes the shift is transposition. Transposition is used by changing the grammatical category from source text into target text. This is done because of the differences in linguistic rules between the two languages. This technique is similar to the modulation technique. The technique of transposition also has two properties: obligatory and optional.

This technique can change the grammatical structure, so it can affect the shift of word class and the shift of both lexical and grammatical forms.

Based on the research finding, the technique used which is caused by the process shift is transposition and modulation, implication, and reduction. It showed that the translator still found difficulties in finding out the specific equivalence for the verbs in source text and target text. Sometimes, certain verb had the meaning in source text but there is no equivalence in target text. So, most of the grammatical features changed in form but it did not change in meaning. This technique can affect the translation result and it can cause the shift either in structure or its semantic feature. Therefore, structure shift or class shift will be very possible to occur in translation dealing with the difference of grammatical rule.

The findings of the research are in line with Vinay and Darbelnet in Newmark (1988: 85) who stated that modulation is a variation through a change of view point, of perspective and very often category of thought. In addition, Molina and Albir (2002) stated that modulation which is used by the translator can change the point of view, focus, or cognitive category in source text so that the shift in translation will be found.

The findings of the research are also similar with Susilowati (2010) and Mardiana (2014) who did research the modulation and transposition in translation. The result of the research stated that the transposition and modulation used by the translator have some impacts on the quality of translation, consumers and the sales target because there were some meaning distortion which were not delivered from the source language. So, the meaning distortion has the impact on the mistakes in using the product which can create serious problem for the consumers.

Moreover, the study conducted by Sumarli (2017) stated that transposition and modulation can change the grammatical category which can cause the shift. If the translation used the transposition techniques appropriately, it would have not shift or meaning distortion can be avoided. But, if it is inappropriate in using transposition technique, it will cause meaning distortion. So, the translation result will influence the translation quality. This is relevant with Catford (1965: 73) who stated that transposition is the shift. While Vinay and Darbelnet in Newmark (1988: 85) stated that shift is the result of the grammatical differences between source text and target text.

Implication contradicts with explication. As Molina and Albir (2002) stated that explication is a translation technique that expresses the meaning directly or that delivers the hidden message into the target language. It also can cause the meaning shift dealing with the difference of grammatical rule between two languages. The purpose of using this technique is to help the reader in understanding the text. Again, the reduction technique is used to make information in the text to be dense from source language into target text. So, the effect of using this technique is that some information will be decreased or even it will be lost in target language. Some process shift examples will be given in the following explanation:

1. Identifying Relative Process to be Relative Attributive Process

Table 3. IRP in Source Text

\begin{tabular}{|l|l|}
\hline Data & Source Text \\
\hline 089.OS.ST & $\begin{array}{l}\text { That's what will lend meaning to the } \\
\text { creed our fathers once declared. }\end{array}$ \\
\hline 090.OS.ST & $\begin{array}{l}\text { That's what will lend meaning to the } \\
\text { creed our fathers once declared. }\end{array}$ \\
\hline
\end{tabular}

IRP: Identifying Relational Process; OS: Obama's Speech; ST: Source Text;

Table 4. ARP in Target Text

\begin{tabular}{|l|l|}
\hline Data & \\
\hline 089.OS.TT & $\begin{array}{l}\text { Ini yang akan memberi arti pada } \\
\text { keyakinan yang dulu di deklarasikan para } \\
\text { pendiri negara kita. }\end{array}$ \\
\hline 090.OS.TT & $\begin{array}{l}\text { Ini yang akan memberi arti pada } \\
\text { keyakinan yang dulu di deklarasikan para } \\
\text { pendiri negara kita. }\end{array}$ \\
\hline
\end{tabular}


In the two examples above, it can be seen from the word 'that' in source text both functions as token. Both clauses in source text are reversible while both clauses in target text are irreversible. It can be seen that the copula 'is' in the two clauses was deleted or implicating in target text. So, it can be said that the translator used implication technique.

The implication technique is a translation technique that involves implying the purpose or message in target text. It is chosen because the grammar of one language is different from the other. The use of this technique is so that the translation and the message can easily be understood in target text. This technique is the opposite of an explicit technique. This technique was chosen as a consequence of the difference of the language system. The impact of the technique potentially causes the shift either in form or in the meaning of the text. However, it will not make the translation quality to be inaccurate.

\section{Mental Process to be Mental Behavior Process}

Table 5. MP in Source Text

\begin{tabular}{|l|l|}
\hline Data & Source Text \\
\hline 066.OS.ST & $\begin{array}{l}\text { We, the people, still believe [[that every } \\
\text { citizen deserves a basic measure of } \\
\text { security and dignity]]. }\end{array}$ \\
\hline 077.OS.ST & $\begin{array}{l}\text { We, the people, still believe [[that our } \\
\text { obligations as Americans are not just to } \\
\text { ourselves]], but to all posterity. }\end{array}$ \\
\hline
\end{tabular}

MP: Mental Process; OS: Obama’s Speech: ST: Source Text

Table 6. MBP in Target Text

\begin{tabular}{|l|l|}
\hline Data & Target Text \\
\hline 066.OS.TT & $\begin{array}{l}\text { Kita, rakyat Amerika, masih yakin } \\
\text { [[bahwa setiap warga berhak atas } \\
\text { keamanan dan martabat yang } \\
\text { mendasar]]. }\end{array}$ \\
\hline 077.OS.TT & $\begin{array}{l}\text { Kita, rakyat Amerika, masih yakin } \\
\text { [[bahwa kewajiban kita sebagai orang } \\
\text { Amerika bukan hanya untuk diri kita } \\
\text { sendiri]], tetapi untuk semua anak cucu. }\end{array}$ \\
\hline
\end{tabular}

MBP: Mental Behavioral Process; OS: Obama’s Speech; TT: Target Text

From both examples above, it can be seen from the verb 'believe' in source text which is translated to be an adjective 'yakin' in Bahasa Indonesia (target text). It can be seen that in the translation result, there was a shift in grammar and process. The technique used by the translator is transposition. The technique used by replacing the grammatical category from source text into target text. It was done because there is a grammatical difference between English and Indonesia. This technique is almost similar with modulation. Transposition technique has also two characteristics. It is obligatory and optional which can change the grammatical structure. So, it will influence the category shift or class shift either lexically or grammatically and will change the process types from source language into target language.

\section{Material Process to be $\theta$ Process}

\section{Table 7. MP in Source Text}

\begin{tabular}{|l|l|}
\hline Data & Source Text \\
\hline 022.OS.ST & $\begin{array}{l}\text { Through blood drawn by lash and blood } \\
\text { drawn by sword, we learned [[that no } \\
\text { union founded on the principles of liberty } \\
\text { and equality could survive half-slave and } \\
\text { half-free]]. }\end{array}$ \\
\hline 023.OS.ST & $\begin{array}{l}\text { Through blood drawn by lash and blood } \\
\text { drawn by sword, we learned [[that no } \\
\text { union founded on the principles of liberty } \\
\text { and equality could survive half-slave and } \\
\text { half-free]]. }\end{array}$ \\
\hline
\end{tabular}

Table 8. $\theta$ Process in Target Text

\begin{tabular}{|l|l|}
\hline Data & Target Text \\
\hline 022.OS.TT & $\begin{array}{l}\text { Melalui cucuran darah karena cambukan } \\
\text { dan cucuran darah karena pedang, kita } \\
\text { tahu [[bahwa tidak ada persatuan yang } \\
\text { didirikan atas dasar prinsip kebebasan } \\
\text { dan kesetaraan dapat bertahan dengan } \\
\text { setengah-budak dan setengah bebas]]. }\end{array}$ \\
\hline 023.OS.TT & $\begin{array}{l}\text { Melalui cucuran darah karena cambukan } \\
\text { dan cucuran darah karena pedang, kita } \\
\text { tahu [[bahwa tidak ada persatuan yang } \\
\text { didirikan atas dasar prinsip kebebasan } \\
\text { dan kesetaraan dapat bertahan dengan } \\
\text { setengah-budak dan setengah bebas]]. }\end{array}$ \\
\hline
\end{tabular}

Based on the data from the examples above, it can be seen from the passive verb 'drawn' which is a material process clause translated to be 'cucuran' is a noun in the target language and it has no process in target language. Indirectly, based on both examples above, the translator used the modulation in meaning as well as transposition in its shape. Actually, through blood drawn by lash can be translated 'melalui darah yang dicucurkan'. But, in this case, the translator decided to translate it as 'melalui 
cucuran darah karena cambukan'. It has the meaning that the sacrifice such as blood drawn has been done by patriots of American founder to get the independence and superiority. The translator decides to use modulation technique (obligatory) caused by the grammatical rule differences. So, the translation result takes place the changing of point of view between source texts into target text.

4. Attributive Relational Process to be Attribute as Process

Table 9. ARP in Source Text

\begin{tabular}{|l|l|}
\hline Data & Target Text \\
\hline 051.OS.ST & $\begin{array}{l}\text { We are true to our creed [[when a little } \\
\text { girl [[borninto the bleakest poverty]] } \\
\text { knows [[that she has the same chance to } \\
\text { succeed as anybody else]]]], because she } \\
\text { is an American; she is free, and she is } \\
\text { equal, not just in the eyes of God but also } \\
\text { in our own. }\end{array}$ \\
\hline
\end{tabular}

OS: Obama's Speech; ST: Source Text: ARP: Attributive Relational Process

Table 10. Attribute as Process in Target Text

\begin{tabular}{|l|l|}
\hline Data & Target Text \\
\hline 051.OS.TT & Kita benar-benar patuh pada keyakinan \\
& kita [[apabila seorang anak perempuan \\
yang lahir dalam kemiskinan yang \\
parah]] tahu [[bahwa ia memiliki \\
kesempatan yang sama untuk berhasil \\
seperti yang lainnya]]]], karena ia \\
adalah warga Amerika, ia hidup dalam \\
kebebasan, dan ia setara, bukan hanya di \\
mata Tuhan tetapi juga di mata kita.
\end{tabular}

In the example above, it can be seen in target text (Bahasa Indonesia) which does not have copula like in English. The pronoun 'we' in the source language functions as 'token' as well as describe the US people. This type of attributive relational clause is intensive clause that has characteristic ' $x$ ' is ' $a$ '. But, in the target language, it can be said that ' $\mathrm{x}$ ' or kita is 'a' or benarbenar patuh pada keyakinan. In other words, it cannot be said kita adalah benar-benar patuh pada keyakinan kita.

The copula pattern in English was influenced by the tenses; meanwhile, Indonesian language does not have a tense which refers to the event. Because of the difference in language system, the copula 'are' was intentionally not translated explicitly to be 'adalah' in bahasa Indonesia by the translator. If the translation of copula 'are' was forced to be translated, it will be less acceptable in target language. It is very clear that the translator used implication which is automatically making the translation to be shifting. Grammatically, the pattern is shifting but the meaning is not.

\section{Trump's Speech Translation}

Table 11. Process Shift in Obama's Speech

\begin{tabular}{|c|l|l|c|c|}
\hline No & $\begin{array}{c}\text { Process in } \\
\text { ST }\end{array}$ & $\begin{array}{c}\text { Process in } \\
\text { TT }\end{array}$ & Freq. & Percentage \\
\hline 1 & MB & ARP & 1 & 0.65 \\
\hline 2 & IRP & ARP & 1 & 0.65 \\
\hline 3 & ARP & Att/process & 1 & 0.65 \\
\hline 4 & Extra-causer & ARP & 1 & 0.65 \\
\hline 5 & Material & ARP & 1 & 0.65 \\
\hline 6 & MB & Att/Process & 1 & 0.65 \\
\hline 7 & IRP & Existential & 1 & 0.65 \\
\hline \multicolumn{2}{|l}{ Total } & & 7 & 4.60 \\
\hline
\end{tabular}

MB: Mental Behavior; IRP: Identifying Relational Process; Att: Attribute;

The shifts which occur in the speech translation above were caused by four techniques applied by the translator. The techniques are shown in a table as follows:

Table 12. Translation Techniques Caused the Process Shift

\begin{tabular}{|c|l|c|c|}
\hline No & $\begin{array}{c}\text { The technique } \\
\text { influence the shift }\end{array}$ & Frequency & Percentage \\
\hline 1 & Modulation & 4 & 2.63 \\
\hline 2 & Implication & 1 & 0.65 \\
\hline 3 & Explication & 1 & 0.65 \\
\hline 4 & Reduction & 1 & 0.65 \\
\hline \multicolumn{2}{|l|}{ Total } & 7 & $4.60 \%$ \\
\hline
\end{tabular}

The three techniques have been explained in Obama's speech above. All of them were almost the same. But, in Trump's speech translation, it found a technique which caused the shift also, that is reduction. This technique is used by compressing existing information on source text. Therefore, it can be said that the reduction implicates the information to target text. This technique is done by implicating or omitting some information. Some translation process shift examples will be given in the 
following explanation:

1. Mental Behavioral Process to be Attributive Relational Process

Table 13. MBP in Source Text

\begin{tabular}{|l|l|}
\hline Data & \\
\hline 021.TS.ST & $\begin{array}{l}\text { The establishment protected itself, but } \\
\text { not the citizens of our country. }\end{array}$ \\
\hline
\end{tabular}

MBP: Mental Behavioral Process; TS: Trump's Speech: ST: Source Text

Table 14. MBP in Target Text

\begin{tabular}{|l|l|}
\hline Data & Target Text \\
\hline 066.TS.TT & $\begin{array}{l}\text { Pembangunan negara ini dilindungi, } \\
\text { tetapi hal serupa tidak dirasakan oleh } \\
\text { warga dari negara kami. }\end{array}$ \\
\hline
\end{tabular}

From the example above, the verb 'protected' (past participle) and there is an auxiliary verb in source text implicitly. The verb 'protected' is active meaning in source text which has the meaning, protected or keep. In this case, keeping the development of US, developing and establishing the human or the citizen of America in every sector. It involves the cognition and behavior domain. The word 'citizens' functions as a sensor and 'the establishment' in target text functions as a micro phenomenon (thing). The translator changes the point of view from source text by applying the modulation. The result is taking place the shift of process types. Passive meaning on verb 'dilindungi' is an attribute which explain the carrier 'pembangunan Amerika'.

2. Attributive Relational Process to be Identifying Relational Process

Table 15. ARP in Source Text

\begin{tabular}{|l|l|}
\hline Data & Source Text \\
\hline 132.TS.ST & $\begin{array}{l}\text { It is time to remember that old wisdom } \\
\text { our soldiers will never forget: that whether } \\
\text { we are black or brown or white, we all } \\
\text { bleed the same red blood of patriots, we } \\
\text { all enjoy the same glorious freedoms, and } \\
\text { we all salute the same great American } \\
\text { Flag. }\end{array}$ \\
\hline
\end{tabular}

ARP: Attributive Relational Process; TS: Trump's Speech: ST: Source Text
Table 16. IRP in Target Text

\begin{tabular}{|l|l|}
\hline Data & Target Text \\
\hline 132.TS.TT & $\begin{array}{l}\text { Ini waktunya untuk mengingat kembali } \\
\text { bahwa kebijaksanaan para pasukan kita } \\
\text { tidak akan pernah lupa; bahwa apakah } \\
\text { kita memiliki warna kulit hitam atau } \\
\text { cokelat atau putih tetapi kita semua } \\
\text { menumpahkan warna darah merah yang } \\
\text { sama, kita semua menikmati kebebasan } \\
\text { yang sama dan memberi hormat kepada } \\
\text { bendera Amerika yang sama. }\end{array}$ \\
\hline
\end{tabular}

Based on the data from the examples above, it can be seen from the source text that there is a copula 'is'. It is a marker that the clause is relational clause, especially attributive relational clause and the carrier is 'it'. It will be different in target text that there is no copula in Bahasa Indonesia in this case as target language. So, it is right that the translator applied the implicit technique. It causes the translation of the process to be shifted. So, it resulted in identifying relational process in source text to be attributive relational process in target text.

\section{CONCLUSION}

Based on the research findings above, it can be concluded that there are 6 kinds of shift in Obama's speech translation. They are: a) identifying relational process into attributive relational process; $b$ ) mental process into mental behavioral process; c) material process into Ø process; d) attributive relational process into attribute conflated with process; e) relational attributive into existential process; and f) material process into attribute conflated with the process. While the shift of translation is caused by 3 translation techniques. They are implication, modulation, and transposition.

Based on Trump's speech translation, it is obtained that there are 6 kinds of shift. They are: a) mental behavior process into attributive relational process; $b$ ) identifying relational process into attributive relational process; c) attributive relational process into attribute conflated with process; d) extra-causer process into attributive relational process into attribute conflated with process; e) material process into attributive relational process into attribute conflated with process; f) mental behavioral process into attribute conflated with process; g) identifying relational process into existential process. The process shift is caused by 4 translation techniques based on the research findings. They are: modulation, implication, explication, and reduction. 
The study threw more lights not just on a particular aspect of translation but also on the systemic functional linguistics in several aspects that need to be studied. One interesting thing to note is that this research focuses on certain technique and its translation quality. For example, the study about literal translation or discursive creation.

Moreover, the systemic functional linguistics can be researched in participants and circumstance element which are all above still under discussion. In addition, the translators are expected to avoid some translation techniques which cause the shift although it cannot change the meaning significantly.

However, starting from the problems classification above, the breakdown of the specific verbal group in process types have not been analyzed yet as well as its language style based on verbal group. It hopefully will be beneficial to a partial re-evaluation of the outcomes. Therefore, to strengthen and sharpen the study, the future research studies are expected to focus on the specific item such as typology of verbal group pattern in process types of transitivity system. It can be political speech, opinion article in mass media, or even it can be based on academic texts or students' scientific writing.

\section{REFERENCES}

Baker, M. (2011). In Other Words: A course book on translation, second edition. London: Rutledge. https://doi.org/10.1075/target.24.1.19che

Bielsa, E., \& Bassnett, S. (2008). Translation in global news. Translation in Global News. https://doi. org/10.4324/9780203890011

Catford, J. C. (1965). A Linguistic Theory of Translation. Language and Language Learning. Retrieved from http://rahbar.iauq.ac.ir/assets/subdomains/rahbar/ files/93/TheoriesOfTranslation/

Darani, L. H. (2014). Persuasive style and its realization through transitivity analysis: A SFL perspective. Procardia - Social and Behavioral Sciences. https:// doi.org/10.1016/j.sbspro.2014.12.066

De Dios, T. (2013). Science Direct Exploring Transitivity Alternations across Dialects: A Preliminary Approach. Procardia - Social and Behavioral Sciences, 95, 425-430. https://doi.org/10.1016/j. sbspro.2013.10.665

Eggins, S. (2004). An Introduction to Systemic Functional Linguistics 2nd Edition.

Halliday, M. A. K., \& Matthiessen, C. M. I. M. (2014). Halliday's Introduction to Functional Grammar. https://doi.org/10.4324/9780203431269

Hatim, B., \& Munday, J. (2013). Translation An Advanced Resource Book. Journal of Chemical Information and Modeling, 53. https://doi.org/10.1017/

\section{CBO9781107415324.004}

He, Q., \& Wen, B. (2015). Reflections on the grammatical category of the than element in English comparative constructions: A corpus-based systemic functional approach. Ampersand. https://doi.org/10.1016/j. amper.2015.08.001

Hidayah, I. (2013). Dampak pergeseran kelompok nomina dalam dua pidato kenegaraan presiden amerika serikat barrack obama dan terjemahannya terhadap kualitas terjemahan. Sebelas Maret University.

Hill-Madsen, A. (2014). Derivation and Transformation: Strategies in Lay-oriented Intralingual Translation, 308. Retrieved from http://pure.au.dk/portal/ files/73870680/Dissertation_AageHM_final.pdf

Idrus, M. M., Nor, N. F. M., \& Ismail, I. S. (2014). Representing Action: Transitivity and Verb Processes in Malaysian and Singaporean Oral Proceedings Over Batu Puteh Island Issue. Procardia - Social and Behavioral Sciences. https://doi.org/10.1016/j. sbspro.2014.02.024

Ignatieva, N., \& Rodríguez-Vergara, D. (2011). Verbal processes in academic language in Spanish: exploring discourse genres within the systemic functional framework. https://doi.org/10.1186/s40554-0150014-9

Isti 'anah, A., \& Id, A. A. (2014). Transitivity Analysis in Four Selected Opinions about Jakarta Governor Election. Journal of Language and Literature, 14(2), $163-175$.

Mardiana, W. (2014). Teknik Transposisi dan Modulasi: Kesepadanan dan Pergeseran dalam Penerjemahan Cerpen Berjudul "My Beloved Edith". Parole, 4(2), 120-130.

Matu, P. M. (2008). Transitivity as a tool for ideological analysis. Journal of Third World Studies; Spring, 25(1), 199-211.

Molina, L., \& Hurtado Albir, A. (2002). Translation Techniques Revisited: A Dynamic and Functionalist Approach. Meta: Journal Des Traducteurs. https:// doi.org/10.7202/008033ar

Munday, J. (2009). Issues in translation studies. The Rutledge companion to translation studies. Retrieved from http://www.google.com/ books?hl=en\&lr=\&id=ictlRLq_pSsC\&oi=fnd\&pg $=$ PA $1 \& \mathrm{dq}=\mathrm{THE}+\mathrm{ROUTLEDGECOMPANION}+\mathrm{T}$ O+TRANSLATION+STUDIES\&ots=9GSEtCp_w \&sig=V2pS1szShe9dpwoSF0IeEWAOMPk

Nababan, M. (2012). Pengembangan model penilaian kualitas terjemahan. Kajian Linguistik Dan Sastra, 24(1), 39-57. Retrieved from https://publikasiilmiah.ums. ac.id/bitstream/handle/11617/2220/4. MANGATUR NABABAN.pdf; sequence $=1$

Newmark, P. (1988). A Textbook of Translation. Text. https:// doi.org/10.1017/CBO9781107415324.004 
Nida, E.A and Taber, C. (1982). The theory and practice of translation. Leiden: E.J. Brill.

Patton, M. Q. (1980). Qualitative evaluation methods. Beverly Hills: Sage Publication.

Pramuditya, R. S. (2016). Analisis Dampak Teknik Penerjemahan terhadap Fungsi Experiential serta Nilai Keakuratan dan Keberterimaan Nominal Group dalam terjemahan Cerpen 'The Adventure of the Veiled Lodger.' Sebelas Maret University.

Purwaningsih, D. R. (2010). Analisis teknik dan kualitas terjemahanu unsur pre-modifier dalam kelompok nomina dalam novel the da vinci code. Sebelas Maret University.

Santosa, R. (2009). SFL and problems of equivalence in translation. Paper presented in Translation Society of Indonesia International conference, Solo.

Seo, S. (2013). Hallidayean transitivity analysis: The Battle for Tripoli in the contrasting headlines of two national newspapers. Discourse and Society, 24(6), 774-791. https://doi.org/10.1177/0957926513503267
Spradley, J. P. (1980). Participant Observation. Harcourt Brace Jovanovich (Vol. 53). Orlando: Harcourt Brace Jovanich Inc. https://doi.org/10.1017/ CBO9781107415324.004

Strauss, A., \& Corbin, J. (2003). Dasar-dasar penelitian kualitatif: tata langkah dan tehnik-tehnik teoritisasi data. Terjemahan. Yogyakarta: Pustaka Pelajar.

Sujono, A., \& Wiratno, T. (2016). A translation analysis of the multiple themes shift in rumi: a spiritual biography from english into indonesian (a systemic functional linguistics approach). International Seminar Prasasti III: Current Research in Linguistics (pp. 92-98). Surakarta: Doctoral Linguistics Program of Sebelas Maret University.

Sumarli, F. (2017). Analisis terjemahan kolokasi budaya spesifik dalam novel the serpent's shadow dan terjemahannya bayangan sang ular karya rick riordan. Sebelas Maret University.

Sutopo, H. (UNS). (2006). Metodologi penelitian kualitatif: Dasar teori dan penerapannya dalam penelitian. Surakarta: UNS Press. 